\title{
Unplanned Urban Growth and Its Potential Impacts on Bird Species in a South American City
}

Tulaci Bhakti ${ }^{1,2}$

João Carlos Pena ${ }^{3}$ (i) 0000-0003-1368-1805

Marcos Rodrigues ${ }^{2}$

\begin{abstract}
South American cities have been expanding extremely fast and with reduced urban planning, which can lead to significant biodiversity loss. In this study, it was assessed the potential consequences of unplanned urban growth on bird species inhabiting an area comprising a mosaic of forest and natural grasslands in the city of Belo Horizonte in Brazil. Considering the lower aboveground biomass, it would be expected grassland patches to be more occupied by humans than forest patches. The bird community inhabiting the area in 2012 was recorded and it was also provided a visual interpretation of satellite imagery for 2012 and 2018. The urban area increased $192.73 \%$, which occurred to the detriment of forest and, especially, grasslands, with a reduction of $10.78 \%$ and $22.12 \%$, respectively. In this area, it was recorded a total of 126 bird species, of which 65\% were classified as of open habitat. It was also discussed the need for better urban planning by incorporating potential impacts on biodiversity and preservation of habitat mosaics within urban landscapes.
\end{abstract}

Keywords: Neotropical city, urban ecology, bird feeding guilds, land use change impacts, habitat mosaic.

\section{Introduction}

Urban landscapes are expanding at accelerated rates, especially in underdeveloped and tropical countries (United Nations, 2018). As a consequence, different habitat types have becoming increasingly disturbed and fragmented, leading to the loss of biodiversity and resulting in negative impacts on ecological processes (Haddad et al., 2015; Wilson et al., 2016). In South American countries, such as Brazil, unplanned and uncontrolled expansion of urban landscapes has been occurring near and within biodiversity hotspots, such as the Atlantic Forest and Cerrado biomes (Güneralp \& Seto, 2013; Reis et al., 2012). Thus, urban ecological studies can help to define planning and management strategies that can harmonize urban growth and development with the maintenance of human well-being and biodiversity conservation.
Studies have demonstrated that urbanization gradients intensity may have negative relationships with species and ecological processes (Clergeau et al., 1998; Concepción et al., 2017; Eötvös et al., 2018; Reale \& Blair, 2005). Peri-urban regions typically harbor greater amounts of natural vegetation cover and contain reduced human population densities than urban areas, which allow the presence of higher species diversity (Canedoli et al., 2018; Snep et al., 2006). This relationship is related to the reduction and loss of resources and habitats that are essential for the maintenance of several species found from peri-urban to urban areas, such as the loss of large and old trees which are necessary for reproduction as well the daily activities of some bird species (Le Roux et al., 2014; Stagoll et al., 2012). On the other hand, even in highly-developed urban centers, the preservation of green areas and the maintenance of native flora can attenuate the effects of urbanization and

1 Universidade Federal de Minas Gerais (UFMG), Instituto de Ciências Biológicas, Programa de Pós-Graduação em Ecologia, Conservação e Manejo de Vida Silvestre, Belo Horizonte, MG, Brasil

2 Universidade Federal de Minas Gerais (UFMG), Instituto de Ciências Biológicas, Departamento de Zoologia, Laboratório de Ornitologia, Belo Horizonte, MG, Brasil

3 Universidade Estadual Paulista (UNESP), Instituto de Biociências, Departamento de Biodiversidade, Laboratório de Ecologia Espacial e Conservação (LEEC), Rio Claro, SP, Brasil 
conserve biodiversity, including the structure of biological communities (Pena et al., 2017; James Barth et al., 2015). Therefore, biodiversity responses to urbanization can be used to guide urban growth and development, especially in the urban fringe, by reducing potential negative effects on native species (Ikin et al., 2012; Stagoll et al., 2010).

Birds are a conspicuous and diverse group of vertebrates and their responses to urbanization are related to their morphological and life-history characteristics (Pena et al., 2017; Croci et al., 2008; Kark et al., 2007). These characteristics, also called functional traits, are related to the ability of the species to thrive in an environment, such as nesting behavior, wing and beak morphologies, size and diet (Luck et al., 2012). Land use modifications and environmental impacts related to urbanization may favor or exclude species, depending on the composition of their functional traits (Ikin et al., 2012; Stagoll et al., 2010). For example, ground nesters and granivorous birds may be negatively affected by urbanization due to the reduction of natural grasslands and high intensity management of lawns and gardens (Pena et al., 2017). Thus, studies have already demonstrated that it is possible to link possible land use interventions with potential impacts on bird communities (Ikin et al., 2012; Stagoll et al., 2010). Therefore, urban planners can use these relationships to reduce the potential impacts of urban expansion by, for example, preserving an adequate quantity and quality of different habitat types.

Regarding this study, it was necessary to discuss the potential consequences of unplanned urban growth on the bird community inhabiting one of the last remnants of natural vegetation in the peri-urban region of the city of Belo Horizonte (Brazil). The area comprises a natural mosaic of forest and grassland patches, typical of the transition zone between the Cerrado and Atlantic Forest biomes. Since 2012, the region has been irregularly occupied by thousands of families due to housing shortage in the city. Thus, the region represents an interesting opportunity to assess how the irregular occupation of a habitat mosaic would affect each phytophysiognomy and the bird species inhabiting each habitat type (forest and grassland patches) (Figure 1). Grasslands are commonly considered the result of deforestation (Veldman et al., 2015), and due to the lower aboveground biomass, it is expected that this habitat type would be more occupied by humans during the process of irregular occupation (Figure 1). Consequently, it is suggested that open-habitat bird species would be more affected by the unplanned urban expansion in the region than forest bird species (Figure 1). Since the region is already partly occupied by population settlements, our results can guide future interventions in considering current and future impacts on biodiversity.

\section{Material and methods}

\subsection{Study area}

The study was conducted in the Isidoro Forest (Figure 2) (1949'10" S, 435 '03" W), the last unprotected remnant of natural vegetation located in the peri-urban region of the city of Belo Horizonte, the capital of Minas Gerais in Brazil. The Isidoro Forest covers an area of almost 970 ha and comprises a mosaic of grassland and forest patches (semi-deciduous forest) (Brandão \& Araújo, 1992). The region was the focus of a study conducted in 2014, in which the vulnerable and rare Three-toed Jacamar, Jacamaralcyon tridactyla was recorded (Duarte et al., 2014).

In 2010, the administration office of the Minas Gerais State Government moved from the center of Belo Horizonte to an

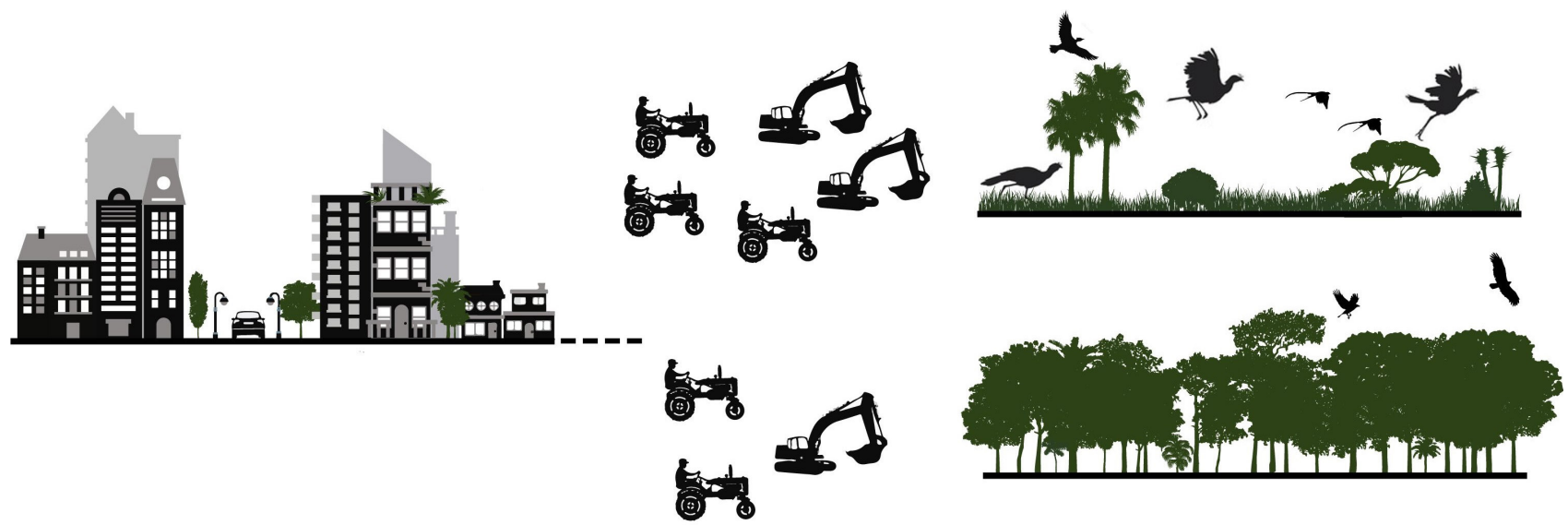

Figure 1. Expectations regarding the potential impacts of the unplanned urban growth on habitat mosaics, specifically in Isidoro Forest (Belo Horizonte, Minas Gerais, Brazil). When cities are expanding in these regions, the lower aboveground biomass of grassland patches may lead to higher human occupation than on forest patches and consequently, higher impacts on the bird community. This figure was developed using resources from Freepik. 


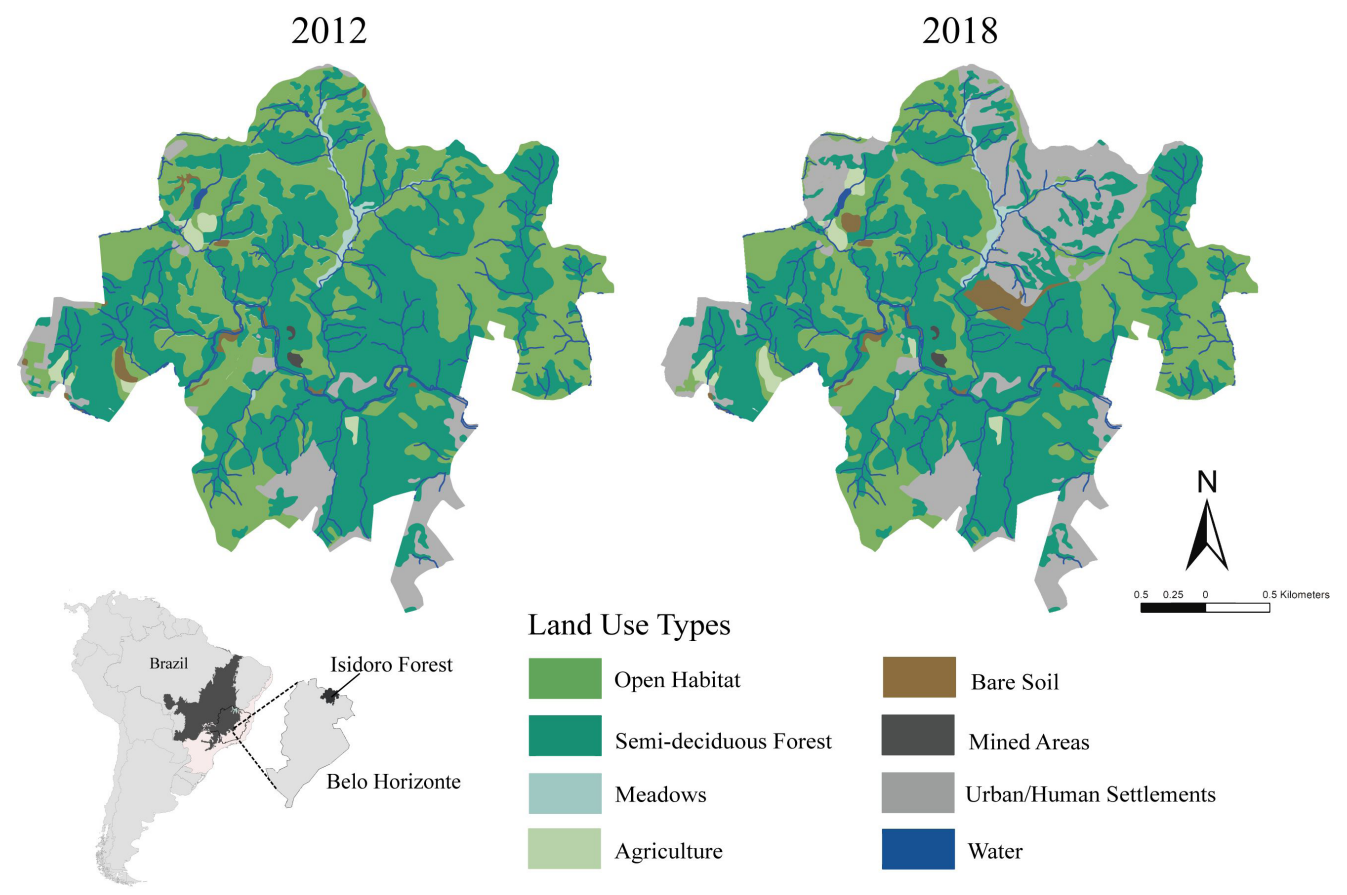

Figure 2. Study area and land use changes between 2012 and 2018 within the Isidoro Forest (Belo Horizonte, Minas Gerais, Brazil).

area near the Isidoro Forest, in which real estate speculation in the region increased (Campos \& Mendonça, 2013). This process was intensified after the Belo Horizonte Municipal Government (BHMG) decided to promote the urban expansion and urbanization of the northern part of the city (Belo Horizonte, 2010). As one of the urban planning initiatives, the BHMG delimited private and public parks within the area of Isidoro Forest as an environmental compensation agreement. A private contractor has been required to implement these conservation units as a counterpart to real estate interventions in the region (Myssior, 2011). However, housing issues in the northern part of Belo Horizonte triggered the irregular occupation of the Isidoro Forest in 2012, and the area became occupied by tens of thousands of low-income families through informal settlements, which resulted in the reduction of natural vegetation cover (Figure 2). The illegal occupations led to a legal battle for repossession that lasted until 2017, when the BHMG had to withdraw from the legal process (Estado de Minas, 2017).

\subsection{Bird community data}

The bird species were sampled by using an exploratory (exhaustive) strategy, and not following a previously planned pattern. The entire area could be explored by walking through the different vegetation types, following streams and watercourses. The sampling occurred between August 2012 and May 2014, and always took place on days with favorable weather (sunny non-windy days) and in the early hours of the morning $(6-10 \mathrm{~h})$, for a total of 54 hours of observation with a total of 18 days. Bird species were identified using field guides (Van Perlo, 2009), and the scientific nomenclature followed Piacentini et al. (2015). The bird species were classified according to feeding guilds (Sick, 1997; Telles \& Dias, 2010) and preferred habitat: forest or open (Sick, 1997). Different estimators were also used to assess the cumulative number of species according to our sampling effort using the Vegan package on R (Oksanen et al., 2019).

It was also considered the bird species registered during an Environmental Impact Assessment (EIA) study performed in the Isidoro Forest in 2011 (Myssior, 2011). Bird species documented in that study and not recorded by our fieldwork, were also included in our species list.

\subsection{Assessment of land use changes}

It was assessed the land use changes that occurred in the area of Isidoro Forest between 2012 and 2018 using Google Earth $^{\mathrm{TM}}$ satellite images from both years. The images were georeferenced and projected into the Universal Transverse Mercator (UTM) system (zone 23S; datum WGS84). Land use types were identified through visual interpretation by using ArcGIS 10.6.1 software in a reference scale of 1:5000. This approach was used to describe the vegetation of Isidoro Forest in 2012, when the bird surveys were conducted, and in 2018, when describing the current state of the region after the irregular occupation. Both classified images were overlapped to assess how the unplanned urban growth has affected the 
different habitat types, especially forest and grassland patches. Then, it was discussed the potential consequences of the land use changes on forest and open-habitat bird species inhabiting the Isidoro Forest.

\section{Results}

A total of 126 bird species were registered in the Isidoro Forest (106 species during fieldwork and 20 species observed only during the study of Environmental Impact Assessment (EIA)), distributed among 38 families (the complete species list is found in Supplementary Material). This diversity is probably higher according to all resulted accumulation curves (Supplementary Material). We could identify eight feeding guilds: insectivores were the most abundant guild (54 species), followed by omnivorous (29), carnivorous (10), frugivorous (9), seedeaters (9), nectarivores (8), piscivorous (6) and detritivores (1) (Figure 3, Supplementary Material). In relation to habitat

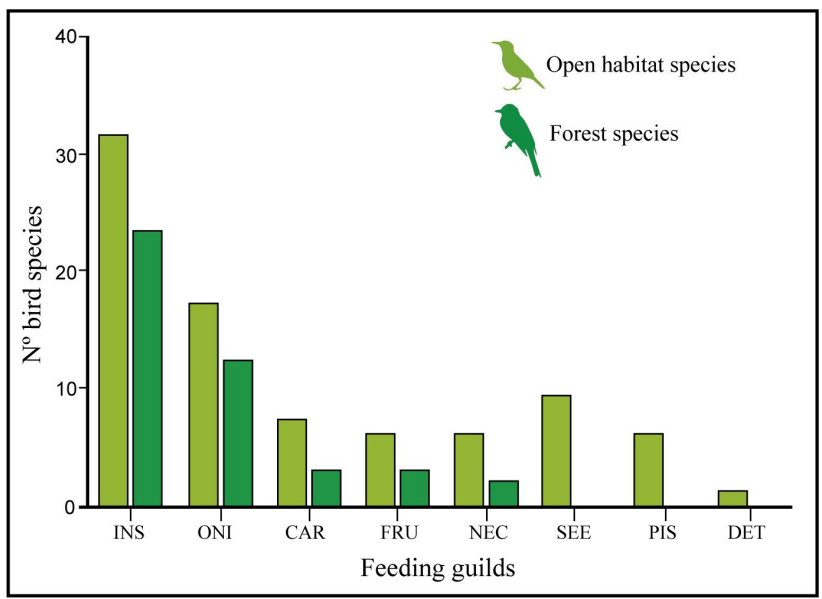

Figure 3. Number of bird species classified according to feeding guilds and habitat preference (forest or open habitat) within the Isidoro Forest (Belo Horizonte, Minas Gerais, Brazil). Feeding guilds: insectivores (INS), omnivorous (ONI), carnivorous (CAR), frugivorous (FRU), seed eaters (SEE), nectarivores (NEC), piscivorous (PIS) and detritivores (DET). preference, 83 species $(65 \%)$ were classified as open-habitat birds, while 43 (35\%) were classified as forest species (Figure 3, Supplementary Material). We also recorded bird species which are considered endemic to the Atlantic Forest [Hemithraupis ruficapilla, Ilicura militaris, Myiornis auricularis, Pyriglena leucoptera, Tachyphonus coronatus and Jacamaralcyon tridactyla (Silva et al., 2004)] and Cerrado [Antilophia galeata and Cyanocorax cristatellus (Silva, 1997)] biomes.

Land use change assessment documented an increase of $192.72 \%$ in urban area within the Isidoro Forest (Figure 2, Table 1). The unplanned urban growth occurred to the detriment of forest and, especially, open-habitat patches, with a reduction of $10.78 \%$ and $22.12 \%$, respectively (Figure 2, Table 1). Most of the urban expansion occurred in the northern part of Isidoro Forest, where it also caused the loss and degradation of meadows and, probably, watercourses in the region (Figure 2, Table 1).

\section{Discussion}

The Isidoro Forest is one of the last remnants of natural vegetation in the peri-urban region of Belo Horizonte. Its heterogeneity comprising a mosaic of forest and grassland habitat patches, favors the occurrence of high diversity of bird species, including species considered endemic to the Atlantic Forest and Cerrado biomes. As we expected, the unplanned urban expansion reduced more than $20 \%$ of the grassland area in relation to its previous coverage in 2012, which is the preferred habitat for more than $65 \%$ of the bird species recorded in Isidoro Forest. The process of urban expansion reduces remnants of natural vegetation, which causes changes in species composition of bird communities (Schütz \& Schulze, 2015). This change is related to how bird species may vary in their utilization of vegetation, such as for nesting sites and foraging (Ikin et al., 2012). Therefore, changes in vegetation structure and composition during the process of urbanization have a direct impact on birds (Ikin et al., 2012).

According to our knowledge, this is the first study attempting to assess the potential consequences of unplanned

Table 1. Land use changes identified within the Isidoro Forest (Belo Horizonte, Minas Gerais, Brazil) between 2012 and 2018.

\begin{tabular}{lccc}
\multicolumn{1}{c}{ Land use type } & Area in 2012 (ha) & Area in 2018 (ha) & \% change \\
Agriculture & 9.20 & 12.87 & 39.89 \\
Bare soil & 7.81 & 17.03 & 118.05 \\
Semi-deciduous Forest ${ }^{1}$ & 523.72 & 467.28 & -10.78 \\
Meadows & 8.89 & 8.59 & -3.37 \\
Mined Areas & 1.39 & 1.39 & 0 \\
Open Habitat & & 275.40 & -22.12 \\
Urban/Human Settlements & 353.63 & 185.12 & 192.73 \\
Water Reservoirs & 63.24 & 1.24 & 19.42 \\
Total & 1.03 & 968.91 & \\
\hline
\end{tabular}

Endemic species recorded during our surveys: ${ }^{1}$ Hemithraupis ruficapilla, Ilicura militaris, and Jacamaralcyon tridactyla (also Vulnerable - BirdLife International, 2018); ${ }^{2}$ Antilophia galeata and Cyanocorax cristatellus. 
and uncontrolled urban expansion on birds in a peri-urban area of a Brazilian city. This type of analysis is important because each species responds differently to the land use changes during urbanization. However, little is known about the differential impact of urban expansion on different phytophysiognomies. Grasslands, such as the Cerrado biome, are preferentially used for human occupation or agricultural lands (Bond \& Parr, 2010; Veech, 2006). Furthermore, grasslands are less represented among Brazilian conservation units (Overbeck et al., 2015). The occupation process of grassland patches within the Isidoro Forest reduces the available habitat for most species recorded in the region, including birds considered endemics to the Cerrado biome.

When assessing the potential effects of the land use changes occurring in the Isidoro Forest on bird feeding guilds, we noticed that most birds were classified as open-habitat species, including all seedeaters. This result was expected since these species forage on herbaceous and shrub species that are typical of open-habitat patches. It has been shown that in South American urban landscapes, seedeaters are adversely affected by the process of urbanization (Pena et al., 2017; Reis et al., 2012). Therefore, considering that only a few fragmented remnants of natural grasslands are available within the landscape of Belo Horizonte, the Isidoro Forest is of critical importance for the preservation of the great diversity of bird species present in the peri-urban region.

We also identified bird species related to freshwater environments. There are many streams and watercourses within the Isidoro Forest that have remained relatively preserved due to limited development in the region. However, we observed that between 2012 and 2018, the urban expansion had already reduced the area of meadow habitat. Furthermore, the process of irregular occupation, due to the lack of urban planning and infrastructure (e.g., basic sanitation facilities), has probably already reduced the integrity and quality of streams and watercourses. Therefore, given the reduced area of meadow habitat and its importance in the preservation of water resources and biodiversity in the region, it is essential that planning and management strategies may be developed to reduce impacts of the urban expansion on meadows, watercourses and streams.

We also observed a reduction in forested area within the Isidoro Forest between 2012 and 2018. In addition to habitat destruction, urban expansion reduces matrix permeability and habitat quality by increasing edge effects (Banks-Leite et al., 2010). Bird species classified as forest specialists are negatively impacted by urbanization, especially species that nest or forage on the ground/understory, like many insectivorous birds (Anjos et al., 2015; Powell et al., 2015). Urban forest patches are important for the maintenance of populations of bird species within cities. This is particularly true for the Isidoro Forest, which harbors six bird species that are endemic to the Atlantic
Forest biome, including the Three-toed Jacamar (Jacamaralcyon tridactyla) (Duarte et al., 2014), which is classified as vulnerable by the International Union for Conservation of Nature (IUCN) (BirdLife International, 2018). Furthermore, it has already been demonstrated that the Isidoro Forest is an important habitat patch for the maintenance of functional connectivity within the urban landscape of Belo Horizonte (Horta et al., 2018). Thus, the negative effects that the unplanned urban expansion has had on the biodiversity in the region are clearly evident.

We were not able to perform bird surveys in the modified areas of Isidoro Forest after the occupation process due to the conflicts occurring in the region. Thus, we do not have data to compare the bird community inhabiting the area in 2018 . However, by classifying species according to habitat preferences, we believe our analysis is a substantial assessment on how the bird community may be influenced by the land use changes occurring in the region. Our results can help in guiding planning and management initiatives for the better occupation of Isidoro Forest. For example, the creation and maintenance of conservation units are essential for the preservation of ecosystem services and biodiversity conservation during peripheral urban growth pattern (Aguilar, 2008). Heterogeneous landscapes, such as the Isidoro Forest, are able to retain a high diversity of bird species (Canedoli et al., 2018; Güneralp \& Seto, 2013; Haila, 2002), which is evident by the high species richness and variety of feeding guilds recorded for the region. Although forest physiognomies have significant social and political appeal for the creation of conservation units (Overbeck et al., 2015, 2007), most of the bird species observed in the Isidoro Forest were classified as open-habitat species. Thus, we highlight the need to preserve natural mosaics, such as those typical regions of the ecotone between the Atlantic Forest and Cerrado biomes.

\section{Conclusions}

We emphasize the importance of assessing how urban expansion can influence different types of environments and phytophysiognomies. Our results could indicate that, only over six years, the urbanized area within Isidoro Forest increased by $192.73 \%$. Due the increase in the area of bare soil nearby the occupied area, it seems that the urban expansion on Isidoro Forest will continue. This rapid and unplanned process has probably been having serious impacts on local biodiversity due habitat loss and fragmentation. Thus, we highlighted the urgent need for planning initiatives, considering not only social needs but also the conservation of the biodiversity in this region. Considering the circumstances, we demonstrated that birds can be used as scientific models to indicate possible impacts of urban expansion on biodiversity. Land use changes affect several feeding guilds, especially when evaluating habitat preferences. More sensitive habitats need special attention, such 
as meadows and watercourses. In this way, it will be possible to harmonize urban development with the maintenance of human quality of life and biodiversity conservation.

\section{Acknowledgements}

TB thanks CAPES for support and ECMVS and MR thanks CNPq and FAPEMIG for grant support. JCCP was supported by São Paulo Research Foundation (FAPESP) (Grant: 2018/00107-3).

\section{Submission status}

Received: 12 Nov., 2019

Accepted: 28 Apr., 2020

Associated Editor: Rodrigo Studart Corrêa

(ORCID: 0000-0002-9422-2629).

\section{Correspondence to Joáo Carlos Pena}

Universidade Estadual Paulista "Júlio de Mesquita Filho" (UNESP), Av. 24 A,1515, CEP 13506-900, Rio Claro, SP, Brasil e-mail: joaocpena@gmail.com

\section{Financial support}

Fundação de Amparo à Pesquisa do Estado de São Paulo (Grant/Award Number: '2018/00107-3'). Fundação de Amparo à Pesquisa do Estado de Minas Gerais (Grant/Award Number: CRA - PPM-00145-14). Conselho Nacional de Desenvolvimento Científico e Tecnológico (Grant/Award Number: 306820/2017-0). Coordenação de Aperfeiçoamento de Pessoal de Nível Superior (Grant/Award Number: 88887.364396/2019-00).

\section{References}

Aguilar AG. Peri-urbanization, illegal settlements and environmental impact in Mexico City. Cities 2008; 25(3): 133-145. http://dx.doi. org/10.1016/j.cities.2008.02.003.

Anjos L, Collins CD, Holt RD, Volpato GH, Lopes EV, Bochio GM. Can habitat specialization patterns of Neotropical birds highlight vulnerable areas for conservation in the Atlantic rainforest, southern Brazil? Biological Conservation 2015; 188: 32-40. http://dx.doi. org/10.1016/j.biocon.2015.01.016.

Banks-Leite C, Ewers RM, Metzger JP. Edge effects as the principal cause of area effects on birds in fragmented secondary forest. Oikos 2010; 119(6): 918-926. http://dx.doi.org/10.1111/j.16000706.2009.18061.x

Belo Horizonte. Câmara Municipal de Belo Horizonte - CMBH. Lei $n^{\circ} 9.959$ de 21 de julho de 2010. Diário Oficial do Município, Belo Horizonte, MG (2010 jul. 21).

BirdLife International. Jacamaralcyon tridactyla. In: International Union for Conservation of Nature and Natural Resources - IUCN. The IUCN Red List of Threatened Species 2018: e.T22682186A131289667. Cambridge: IUCN; 2018. http://dx.doi.org/10.2305/IUCN.UK.20182.RLTS.T22682186A131289667.en.
Bond WJ, Parr CL. Beyond the forest edge: ecology, diversity and conservation of the grassy biomes. Biological Conservation 2010; 143(10): 2395-2404. http://dx.doi.org/10.1016/j.biocon.2009.12.012.

Brandão M, Araújo MG. Cobertura Vegetal do Município de Belo Horizonte, MG. Daphne Revista do Herbário PAMG 1992; 2: 5-12.

Campos PR, Mendonça JG. Estrutura socioespacial e produção habitacional na Região Metropolitana de Belo Horizonte: novas tendências. In: Cardoso AL, editor. O programa Minha Casa Minha Vida e seus efeitos territoriais. Rio de Janeiro: Letra Capital; 2013.

Canedoli C, Manenti R, Padoa-Schioppa E. Birds biodiversity in urban and periurban forests: environmental determinants at local and landscape scales. Urban Ecosystems 2018; 21(4): 779-793. http:// dx.doi.org/10.1007/s11252-018-0757-7.

Clergeau P, Savard JPL, Mennechez G, Falardeau G. Bird abundance and diversity along an urban-rural gradient: a comparative study between two cities on different continents. The Condor 1998; 100(3): 413-425. http://dx.doi.org/10.2307/1369707.

Concepción ED, Götzenberger L, Nobis MP, de Bello F, Obrist $\mathrm{MK}$, Moretti M. Contrasting trait assembly patterns in plant and bird communities along environmental and human-induced land-use gradients. Ecography 2017; 40(6): 753-763. http://dx.doi. org/10.1111/ecog.02121.

Croci S, Butet A, Clergeau P. Does urbanization filter birds on the basis of their biological traits? The Condor 2008; 110(2): 223-240. http://dx.doi.org/10.1525/cond.2008.8409.

Duarte TBF, Castro Pena JC, Rodrigues M. Novo registro do cuitelão Jacamaralcyon tridactyla (Vieillot, 1817) em fragmento florestal urbano de Belo Horizonte, Minas Gerais. Atualidades Ornitológicas 2014; 182: 24.

Eötvös CB, Magura T, Lövei GL. A meta-analysis indicates reduced predation pressure with increasing urbanization. Landscape and Urban Planning 2018; 180: 54-59. http://dx.doi.org/10.1016/j. landurbplan.2018.08.010.

Estado de Minas. PBH desiste de reintegração de posse da Ocupação Izidora, em Belo Horizonte [online]. Estado de Minas, Belo Horizonte (2017 mar.) [cited 2019 Sept 3]. Available from: https://www.em.com. br/app/noticia/gerais/2017/03/17/interna_gerais,855257/pbhdesiste-de-reintegracao-de-posse-da-ocupacao-izidora-em-bh.shtml

Güneralp B, Seto KC. Futures of global urban expansion: uncertainties and implications for biodiversity conservation. Environmental Research Letters 2013; 8(1): 10. http://dx.doi.org/10.1088/17489326/8/1/014025.

Haddad NM, Brudvig LA, Clobert J, Davies KF, Gonzalez A, Holt $\mathrm{RD}$ et al. Habitat fragmentation and its lasting impact on Earth's ecosystems. Science Advances 2015; 1(2): e1500052. http://dx.doi. org/10.1126/sciadv.1500052. PMid:26601154.

Haila Y. A conceptual genealogy of fragmentation research: from island biogeography to landscape ecology. Ecological Applications 2002; 12: 321-334.

Horta MB, Bhakti T, Cordeiro PF, Carvalho-Ribeiro SM, Fernandes GW, Goulart FF. Functional connectivity in urban landscapes promoted by Ramphastos toco (Toco Toucan) and its implications for policy making. Urban Ecosystems 2018; 21(6): 1-15. http://dx.doi. org/10.1007/s11252-018-0789-Z. 
Ikin K, Knight E, Lindenmayer DB, Fischer J, Manning AD. Linking bird species traits to vegetation characteristics in a future urban development zone: implications for urban planning. Urban Ecosystems 2012; 15(4): 961-977. http://dx.doi.org/10.1007/s11252-012-0247-2.

James Barth B, Ian FitzGibbon S, Stuart Wilson R. New urban developments that retain more remnant trees have greater bird diversity. Landscape and Urban Planning 2015; 136: 122-129. http:// dx.doi.org/10.1016/j.landurbplan.2014.11.003.

Kark S, Iwaniuk A, Schalimtzek A, Banker E. Living in the city: can anyone become an "urban exploiter"? Journal of Biogeography 2007; 34(4): 638-651. http://dx.doi.org/10.1111/j.1365-2699.2006.01638.x.

Le Roux DS, Ikin K, Lindenmayer DB, Manning AD, Gibbons P. The future of large old trees in urban landscapes. PLoS One 2014; 9(6): e99403. http://dx.doi.org/10.1371/journal.pone.0099403. PMid:24941258.

Luck GW, Lavorel S, McIntyre S, Lumb K. Improving the application of vertebrate trait-based frameworks to the study of ecosystem services. Journal of Animal Ecology 2012; 81(5): 1065-1076. http:// dx.doi.org/10.1111/j.1365-2656.2012.01974.x. PMid:22435774.

Myssior S. Estudo de impacto ambiental: granja Werneck. Belo Horizonte: Mys Projetos Sustentáveis; 2011.

Oksanen J, Blanchet FG, Friendly M, Kindt R, Legendre P, McGlinn $\mathrm{D}$ et al. vegan: Community Ecology Package. R package version 2.56 [online]. Vienna: R Foundation for Statistical Computing; 2019 [cited 2019 Sept 3]. Available from: https://CRAN.R-project.org/ package $=$ vegan

Overbeck GE, Müller SC, Fidelis A, Pfadenhauer J, Pillar VD, Blanco CC et al. Brazil's neglected biome: the South Brazilian Campos. Perspectives in Plant Ecology, Evolution and Systematics 2007; 9(2): 101-116. http://dx.doi.org/10.1016/j.ppees.2007.07.005.

Overbeck GE, Vélez-Martin E, Scarano FR, Lewinsohn TM, Fonseca CR, Meyer ST et al. Conservation in Brazil needs to include nonforest ecosystems. Diversity $\backsim$ Distributions 2015; 21(12): 1455-1460. http://dx.doi.org/10.1111/ddi.12380.

Piacentini V, Aleixo A, Agne CE, Maurício GN, Pacheco JF, Bravo GA et al. Annotated checklist of the birds of Brazil by the Brazilian Ornithological Records Committee. Revista Brasileira de Ornitologia 2015; 23(2): 91-298. http://dx.doi.org/10.1007/BF03544294.

Powell LL, Cordeiro NJ, Stratford JA. Ecology and conservation of avian insectivores of the rainforest understory: A pantropical perspective. Biological Conservation 2015; 188: 1-10. http://dx.doi. org/10.1016/j.biocon.2015.03.025.

Reale JA, Blair RB. Nesting success and life-history attributes of bird communities along an urbanization gradient. Urban Habitats 2005; 3: 1-24.

Reis E, López-Iborra GM, Pinheiro RT. Changes in bird species richness through different levels of urbanization: implications for biodiversity conservation and garden design in Central Brazil. Landscape and Urban Planning 2012; 107(1): 31-42. http://dx.doi. org/10.1016/j.landurbplan.2012.04.009.
Schütz C, Schulze CH. Functional diversity of urban bird communities: effects of landscape composition, green space area and vegetation cover. Ecology and Evolution 2015; 5(22): 5230-5239. http://dx.doi. org/10.1002/ece3.1778. PMid:30151126.

Sick H. Ornitologia brasileira. Rio de Janeiro: Nova Fronteira; 1997.

Silva JMC, Sousa MC, Castelletti CHM. Areas of endemism for passerine birds in the Atlantic forest, South America. Global Ecology and Biogeography 2004; 13(1): 85-92. http://dx.doi.org/10.1111/j.1466882X.2004.00077.x.

Silva JMC. Endemic bird species and conservation in the Cerrado Region, South America. Biodiversity and Conservation 1997; 6(3): 435-450. http://dx.doi.org/10.1023/A:1018368809116.

Snep RPH, Opdam PFM, Baveco JM, WallisDeVries MF, Timmermans W, Kwak RGM et al. How peri-urban areas can strengthen animal populations within cities: a modeling approach. Biological Conservation 2006; 127(3): 345-355. http://dx.doi.org/10.1016/j. biocon.2005.06.034.

Stagoll K, Lindenmayer DB, Knight E, Fischer J, Manning AD. Large trees are keystone structures in urban parks. Conservation Letters 2012; 5(2): 115-122. http://dx.doi.org/10.1111/j.1755-263X.2011.00216.x.

Stagoll K, Manning AD, Knight E, Fischer J, Lindenmayer DB. Using bird-habitat relationships to inform urban planning. Landscape and Urban Planning 2010; 98(1): 13-25. http://dx.doi.org/10.1016/j. landurbplan.2010.07.006.

Pena JCC, Martello F, Ribeiro MC, Armitage RA, Young RJ, Rodrigues $\mathrm{M}$. Street trees reduce the negative effects of urbanization on birds. PLoS One 2017; 12(3): e0174484. http://dx.doi.org/10.1371/journal. pone.0174484. PMid:28333989.

Telles M, Dias MM. Bird communities in two fragments of Cerrado in Itirapina, Brazil. Brazilian Journal of Biology $=$ Revista Brasileira de Biologia 2010; 70(3): 537-550. http://dx.doi.org/10.1590/S151969842010000300010. PMid:20730340.

United Nations. Department of Economic and Social Affairs Population Division. World urbanization prospects. New York: United Nations; 2018.

Van Perlo B. A field guide to the birds of Brazil. New York: Oxford University Press; 2009.

Veech JA. A comparison of landscapes occupied by increasing and decreasing populations of grassland birds. Conservation Biology 2006; 20(5): 1422-1432. http://dx.doi.org/10.1111/j.15231739.2006.00487.x. PMid:17002760.

Veldman JW, Buisson E, Durigan G, Fernandes GW, Le Stradic S, Mahy G et al. Toward an old-growth concept for grasslands, savannas, and woodlands. Frontiers in Ecology and the Environment 2015; 13(3): 154-162. http://dx.doi.org/10.1890/140270.

Wilson MC, Chen XY, Corlett RT, Didham RK, Ding P, Holt RD et al. Habitat fragmentation and biodiversity conservation: key findings and future challenges. Landscape Ecology 2016; 31(2): 219-227. http://dx.doi.org/10.1007/s10980-015-0312-3. 


\section{Supplementary Material}

Supplementary material accompanies this paper.

Unplanned urban growth and its potential impacts on bird species in a South American city. Supplementary Material Accumulation curves

Unplanned urban growth and its potential impacts on bird species in a South American city. Supplementary Material - Species List This material is available as part of the online article on http://www.scielo.br/floram 